\title{
PERBEDAAN HASIL BELAJAR SISWA PADA PEMBELAJARAN FISIKA DENGAN PENDEKATAN "IDEAL" TERBIMBING MENGGUNAKAN METODE EKSPERIMEN DAN DEMONSTRASI
}

\author{
Bondan Priyandaru ${ }^{1}$ \\ ${ }^{1}$ MTs Muhammadiyah Sodo, Jl. Ki Ageng Giring, Sodo, Paliyan, Gunungkidul \\ Email: boldline06@gmail.com
}

\begin{abstract}
ABSTRAK
Penelitian ini bertujuan untuk mengetahui perbedaan hasil belajar fisika pada pembelajaran dengan pendekatan "IDEAL" terbimbing menggunakan metode eksperimen dan metode demonstrasi pada pokok bahasan pengukuran di SMP N 1 Tanjungsari. Hasil belajar tersebut mencakup ranah kognitif dan psikomotorik. Jenis penelitian ini adalah penelitian eksperimen semu yang menggunakan rancangan eksperimen pretest-posttest (pada ranah kognitif). Sampel dalam penelitian ini ditentukan dengan teknik random dengan menggunakan rumus Cohran. Populasi dari penelitian ini adalah seluruh siswa kelas VII SMP Negeri 1 Tanjungsari, dan sampelnya adalah 28 siswa dari kelas VII A sebagai kelas eksperimen yang diberikan pengajaran dengan pendekatan "IDEAL" terbimbing dengan metode eksperimen dan 28 siswa dari kelas VII B sebagai kelas kontrol yang diberikan pengajaran dengan pendekatan "IDEAL" terbimbing dengan metode demonstrasi. Metode pengujian hipotesis yang digunakan adalah independent sample t-test. Hasil penelitian ini menunjukkan bahwa tidak ada perbedaan yang signifikan pada hasil belajar siswa ranah kognitif antara kelas eksperimen dengan kelas kontrol tetapi ada perbedaan hasil belajar siswa yang signifikan antara kelas eksperimen dengan kelas kontrol pada ranah psikomotorik.
\end{abstract}

Kata kunci: pendekatan “IDEAL” terbimbing, eksperimen, demonstrasi

\begin{abstract}
This study discusses the physics learning outcomes of learning by obtaining guided "IDEAL" using the experimental method and demonstration method on the subject of measurements at SMP N 1 Tanjungsari. The learning outcomes complement the cognitive and psychomotor domains. This type of research is an experimental study using a pretestposttest experimental design (in the realm of cognitive). The sample in this study was determined by random technique using the Cohran formula. The population of this study were all VII grade students of SMP Negeri 1 Tanjungsari, and the sample was 28 students from class VII who were given an experimental class supported by "IDEAL" guided by the experimental method and 28 students from class VII B as a control class given "IDEAL "Guided by the demonstration method. The hypothesis testing method used is independent sample t-test. The results showed that there was no significant difference in cognitive domain student learning outcomes between the experimental class and the control class but there were significant differences in student learning outcomes between the experimental class and the control class in the psychomotor domain.
\end{abstract}

Keywords: "IDEAL" approach guided, experiments, demonstrations

DOI: http://dx.doi.org/10.15575/jtlp. v3i1.6540

Received: 21 Desember 2017 ; Accepted: 30 Januari 2018 ; Published: 1 Maret 2018 


\section{PENDAHULUAN}

Berdasarkan observasi dan interview terhadap sejumlah siswa yang dilakukan sebelum penelitian, pembelajaran fisika di SMP N 1 Tanjungsari jarang dilakukan dengan melakukan eksperimen sehingga hal ini membuat pemahaman siswa tentang eksperimen dan halhal yang terkait dengannya masih rendah dan kemampuan psikomotorik siswa kurang berkembang sehingga perlu pemilihan pendekatan dan metode pembelajaran yang dapat mengatasi masalah tersebut. Diantara metode pembelajaran yang dapat diterapkan dalam kegiatan belajar mengajar adalah metode eksperimen dan metode demonstrasi.

Metode eksperimen adalah cara penyajian bahan pelajaran dimana siswa melakukan percobaan dengan mengalami untuk membuktikan sendiri suatu pertanyaan atau hipotesis yang dipelajari. Dalam metode ini siswa diberi kesempatan untuk mengalami sendiri atau melakukan sendiri, mengikuti proses, mengamati suatu proses, menganalisis, membuktikan dan menarik kesimpulan sendiri tentang suatu objek, keadaan atau proses sesuatu. Kelebihan menggunakan metode eksperimen yaitu dapat membuat siswa lebih percaya atas kebenaran atau kesimpulan berdasarkan percobaannya sendiri, dapat mengembangkan sikap untuk mengadakan studi eksploratoris tentang sains dan teknologi, memperkaya pengalaman dengan hal-hal yang bersifat objektif dan realitis, mengembangkan sikap berpikir ilmiah dan hasil belajar akan lebih tahan lama pada diri siswa, metode ini efektif digunakan untuk kelas dengan jumlah siswa yang cukup banyak, akan tetapi harus tersedia peralatan yang cukup untuk memenuhi jumlah siswa tersbut.

Sedangkan metode demonstrasi adalah metode mengajar dengan cara memperagakan barang, kejadian, aturan dan urutan melakukan kegiatan, baik secara langsung maupun melalui penggunaan media pengajaran yang relevan dengan pokok bahasan atau materi yang sedang disajikan. Kelebihan metode demonstrasi yaitu siswa akan melihat pengalaman belajar langsung setelah melihat langkah demi langkah suatu proses kerja dan hasil dari sebuah proses pengerjaan sesuatu, perhatian siswa dapat dipusatkan kepada hal-hal yang dianggap penting oleh guru sehingga hal yang penting itu dapat diamati secara teliti, dapat membimbing peserta didik kearah berpikir yang sama dalam satu saluran pikiran yang sama, ekonomis dalam jam pelajaran di sekolah, dan beberapa persoalan yang menimbulkan pertanyaan atau keraguan dapat diperjelas waktu proses demonstrasi. Metode demonstrasi dapat digunakan meski hanya tersedia peralatan yang sedikit, akan tetapi akan efektif bila digunakan untuk kelas dengan jumlah siswa yang relatif sedikit sehingga semua siswa dapat melihat proses demonstrasi dengan baik.

Salah satu jenis pendekatan yang dapat dipakai dalam proses pembelajaran adalah pendekatan "IDEAL" terbimbing (identify problem, define terms, explore stretegys, act on the strategy, look at the effects), yang terdiri dari langkah-langkah: pertama adalah Identify problem yakni mengidentifikasi permasalahan dari suatu materi yang akan dipelajari. Pada tahap ini guru membimbing siswa agar mereka dapat menentukan masalah-masalah yang berkaitan dengan materi. Langkah kedua adalah define terms yakni mendefinisikan istilah agar memudahkan siswa dalam memahami materi yang dipelajari. Langkah ketiga adalah explore strategy yakni pemilihan cara-cara, siswa diberikan kebebasan untuk memilih dan mencoba-coba cara yang akan digunakannya sehingga setelah mereka mengeksplorasi berbagai macam cara diharapkan mereka dapat menentukan cara mana yang paling baik, mudah dan paling cocok untuk mereka tempuh. Langkah keempat adalah act on the strategy yakni penggunaan cara, setelah mencoba berbagai macam cara dan siswa telah menemukan cara mana yang paling baik untuk digunakan maka langkah berikutnya adalah menerapkan cara tersebut untuk memecahkan masalah yang sedang mereka hadapi. Langkah kelima adalah look at the effects yakni melihat pengaruh dari 
penggunaan cara yang telah mereka pilih, dengan cara membandingkan hasil dari pemakaian berbagai cara tersebut.

Apabila pembelajaran fisika disesuaikan dengan pendekatan ini maka diharapkan pemahaman siswa terhadap konsep fisika akan lebih meningkat sehingga dapat menyelesaikan permasalahan-permasalahan terkait dengan fisika termasuk menyelesaikan soal ujian akhir dengan baik sehingga angka ketidaklulusan siswa dalam ujian akhir pun bisa diperkecil. Oleh karena itu perlu dilakukan penelitian lebih lanjut tentang perbedaan hasil belajar pada pembelajaran fisika dengan pendekatan "IDEAL" terbimbing menggunakan metode eksperimen dan demonstrasi pada pokok bahasan pengukuran di SMP Negeri 1 Tanjungsari kelas VII semester 1.

\section{METODE PENELITIAN}

Penelitian ini bersifat kuasi eksperimental, di mana diambil dua kelas sampel sebagai kelas eksperimen dan kelas kontrol. Desain penelitian yang digunakan adalah Random Pretest-Posttest Comparison Group Design. Populasi dalam penelitian adalah seluruh siswa kelas VII SMP N 1 Tanjungsari yang tercatat belajar pada tahun ajaran 2009/2010 yaitu sebanyak 102 siswa. Siswa-siswa ini terbagi dalam tiga kelas yaitu VIIA, VIIB, dan VIIC. Teknik pengambilan sample dilakukan dengan cara Random bersyarat dengan melakukan pengundian bagi siswa yang memenuhi syarat sample. Kelas sample ada kelas, yaitu kelas VIIA dan kelas VIIB, jumlah siswa ari kedua kelas sebanyak 67siswa. Kelas VIIA mendapat pembelajaran menggunakan pendekatan "IDEAL" terbimbing dengan metode eksperimen dan kelas VIIB mendapat pembelajaran menggunakan pendekatan "IDEAL" terbimbing dengan metode demonstrasi. Masingmasing kelas eksperimen diambil 28 siswa sebagai sampel penelitian.

Teknik analisa data yang dipergunakan dibagi menjadi dua tahap. Tahap pertama ialah dengan melakukan uji prasyarat analisis guna menentukan jenis analisis apakah yang akan digunakan untuk menguji hipotesis penelitian. Sedangkan tahap kedua dari analisis data adalah menguji hipotesis yang telah diajukan.

1. Uji Persyaratan Analisis

Sebelum analisis dilakukan, terlebih dahulu harus dilakukan uji persyaratan analisis. Langkah untuk menentukan teknik analisis yang seharusnya dilakukan. Pengujian tersebut meliputi:

a) Normalitas Sebaran Data

Pengujian normalitas data menggunakan chikuadrat, pengujian normalitas data dengan chikuadrat dilakukan dengan cara membandingkan kurve normal yang terbentuk dari data yang telah terkumpul dengan kurve normal/standar. Bila harga chi-kuadrat hitung lebih kecil dari pada chikuadrat tabel, maka distribusi data dinyatakan normal, dan bila lebih besar dinyatakan tidak normal. Uji normalitas digunakan untuk mengetahui apakah data berdistribusi normal ataukah tidak. Menurut Triton (2006: 79) persyaratan data disebut normal jika probabilitas atau $\mathrm{P}>0,05$ pada uji normalitas Kolmogorov Smirnov.

b) Homogenitas Varians

Uji Homogenitas varians dimaksudkan untuk mengetahui apakah sampel yang diambil secara acak berasal dari populasi yang homogen atau tidak. Untuk mengetahui homogenitas data digunakan uji-F. Menurut Triton (2006: 175), ujiF sampel penelitian dapat dikatakan berasal dari populasi yang homogen apabila harga probabilitas perhitungan lebih besar dari 0,05 pada taraf signifikansi $5 \%$ atau Fhitung $<$ Ftabel $5 \%$.

\section{Uji Hipotesis}

Berdasarkan uji persyaratan analisis yang telah dilakukan maka dapat ditentukan bahwa hipotesis akan diuji menggunakan independent sample test. Uji ini digunakan karena data penelitian terdistibusi normal dan bersifat homogen. Kriteria penerimaan atau penolakan H0 pada taraf signifikansi $5 \%$ dengan menggunakan program SPSS 16. adalah, apabila thitung > ttabel maka H0 ditolak, akan tetapi jika thitung < ttabel maka HO diterima. Penerimaan atau penolakan $\mathrm{HO}$ juga dapat dilihat melalui 
probabilitas (signifikansi) yaitu apabila probabilitas (signifikansi) > 0,05 maka $\mathrm{H0}$ diterima, demikian sebaliknya jika probabilitas (signifikansi) < 0,05 maka H0 ditolak. Dalam penelitian ini dibandingkan dua cara pembelajaran untuk mengetahui apakah terdapat perbedaan yang signifikan hasil belajar fisika siswa pada ranah kognitif dari penggunaan pendekatan "IDEAL" terbimbing dengan metode eksperimen dan metode demonstrasi. Uji hipotesis perbedaan hasil belajar kognitif dilakukan terhadap Absolute Gain dan Standard Gain dari hasil belajar kognitif.

\section{HASIL DAN PEMBAHASAN}

A. Data Hasil Penelitian

1. Data Kemampuan Awal Kognitif Siswa

Melalui pretest terhadap kemampuan kognitif siswa pada pokok bahasan pengukuran, didapatkan data kemampuan awal kognitif siswa pada dua kelas eksperimen yang berupa skor hasil uji kemampuan awal siswa. Kemampuan awal kognitif siswa ini diperoleh melalui tes hasil belajar ranah kognitif siswa secara ringkas dapat dilihat pada Tabel 1.

Tabel 1. Kemampuan Awal Kognitif Siswa

\begin{tabular}{lcccc}
\hline \multirow{2}{*}{ Kelas } & \multirow{2}{*}{ Rerata } & \multirow{2}{*}{$\begin{array}{c}\text { Simpang } \\
\text { an Baku }\end{array}$} & $\begin{array}{c}\text { Tere } \\
\text { ndah }\end{array}$ & $\begin{array}{c}\text { Terti } \\
\text { nggi }\end{array}$ \\
\hline Eksperimen & 14.39 & 4,56 & 8 & 25 \\
Kontrol & 13.96 & 4,26 & 7 & 23 \\
\hline
\end{tabular}

2. Data Hasil Belajar Ranah Kognitif Siswa

Melalui posttest terhadap kemampuan kognitif siswa pada pokok bahasan pengukuran menggunakan tes hasil belajar ranah kognitif siswa didapatkan data hasil belajar ranah kognitif fisika siswa pada dua kelas eksperimen. Secara ringkas, data dapat disajikan pada Tabel 2.

Tabel 2. Data Hasil Belajar Kognitif Siswa

\begin{tabular}{lcccc}
\hline \multirow{2}{*}{ Kelas } & \multirow{2}{*}{$\begin{array}{c}\text { Rera } \\
\text { ta }\end{array}$} & $\begin{array}{c}\text { Simpan } \\
\text { gan }\end{array}$ & \multicolumn{2}{c}{ Skor } \\
\cline { 4 - 5 } & Baku & Terend & Tertin \\
ah & ggi \\
\hline $\begin{array}{l}\text { Eksperi } \\
\text { men }\end{array}$ & 20.6 & 6,39 & 9 & 33 \\
& 0 & & &
\end{tabular}

\begin{tabular}{|c|c|c|c|c|}
\hline \multirow[b]{2}{*}{ Kelas } & \multirow[b]{2}{*}{$\begin{array}{c}\text { Rera } \\
\text { ta }\end{array}$} & \multirow{2}{*}{$\begin{array}{c}\text { Simpan } \\
\text { gan } \\
\text { Baku }\end{array}$} & \multicolumn{2}{|c|}{ Skor } \\
\hline & & & $\begin{array}{c}\text { Terend } \\
\text { ah }\end{array}$ & $\begin{array}{c}\text { Tertin } \\
\text { ggi }\end{array}$ \\
\hline Kontrol & $\begin{array}{c}18.3 \\
9\end{array}$ & 5,26 & 7 & 27 \\
\hline
\end{tabular}

3. Data Peningkatan Hasil Belajar Ranah Kognitif Siswa

Berdasarkan data kemampuan awal kognitif siswa dan data hasil belajar fisika pada ranah kognitif, diperoleh data peningkatan hasil belajar kognitif fisika siswa pada pokok bahasan pengukuran sebelum dan setelah diberikan perlakuan. Peningkatan ini dinyatakan dengan nilai Absolute Gain dan Standard Gain. Secara ringkas, data dapat disajikan pada Tabel 3.

Tabel 3. Rerata Peningkatan Hasil Belajar Kognitif

\begin{tabular}{lcc}
\hline \multicolumn{1}{c}{ Kelas } & Absolute Gain & $\begin{array}{c}\text { Standard } \\
\text { Gain }\end{array}$ \\
\hline Eksperimen & 6.21 & 0.57 \\
Kontrol & 4.43 & 0.31 \\
\hline
\end{tabular}

4. Data Hasil Belajar Ranah Psikomotorik Siswa Berikut ini disajikan data hasil belajar psikomotor siswa dari LKS 1, LKS 2, LKS 3, LKS 4 dan LKS 5. Secara ringkas data dapat dilihat pada Tabel 4.

Tabel 4. Data Kemampuan Psikomotor Siswa

\begin{tabular}{|c|c|c|c|c|c|}
\hline \multirow{2}{*}{$\begin{array}{c}\mathrm{LK} \\
\mathrm{S}\end{array}$} & \multirow[b]{2}{*}{ Kelas } & \multirow[b]{2}{*}{ Rerata } & \multirow[b]{2}{*}{$\begin{array}{l}\text { Simpang } \\
\text { an Baku }\end{array}$} & \multicolumn{2}{|c|}{ Skor } \\
\hline & & & & $\begin{array}{c}\text { Terend } \\
\text { ah }\end{array}$ & $\begin{array}{c}\text { Terting } \\
\text { gi }\end{array}$ \\
\hline \multirow[t]{2}{*}{1} & $\begin{array}{l}\text { Eksperi } \\
\text { men }\end{array}$ & 16.46 & 2.35 & 12.5 & 18 \\
\hline & Kontrol & 13.68 & 1.95 & 10,5 & 17,5 \\
\hline \multirow[t]{2}{*}{2} & $\begin{array}{l}\text { Eksperi } \\
\text { men }\end{array}$ & 14.98 & 1.60 & 12 & 18 \\
\hline & Kontrol & 13.48 & 1.95 & 9,5 & 17,5 \\
\hline \multirow[t]{2}{*}{3} & $\begin{array}{l}\text { Eksperi } \\
\text { men }\end{array}$ & 16.38 & 1.60 & 13 & 18 \\
\hline & Kontrol & 14.09 & 1.99 & 12 & 17,5 \\
\hline \multirow[t]{2}{*}{4} & $\begin{array}{l}\text { Eksperi } \\
\text { men }\end{array}$ & 14.91 & 2.08 & 11 & 18 \\
\hline & Kontrol & 14.03 & 1.78 & 12 & 18 \\
\hline \multirow[t]{2}{*}{5} & $\begin{array}{l}\text { Eksperi } \\
\text { men }\end{array}$ & 14.98 & 2.35 & 12 & 18 \\
\hline & Kontrol & 13.55 & 1.87 & 9,5 & 17,5 \\
\hline
\end{tabular}


B. Data Hasil Pengujian Persyaratan Analisis Perhitungan uji persyaratan analisis pada penelitian ini meliputi uji normalitas sebaran data, dan uji homogenitas varians. Perhitungan dari analisis ini dilakukan menggunakan program SPSS versi 16. Ringkasan hasil analisis dari masing-masing pengujian ditampilkan pada Tabel 5 dan 6.

1. Uji Normalitas

Tabel 5. Data Uji Normalitas dengan Kolmogorov Smirnov pada uji kognitif Untuk

\begin{tabular}{|c|c|c|}
\hline \multicolumn{3}{|c|}{ Satu Sampel } \\
\hline Jenis Data & $\begin{array}{c}\text { Taraf } \\
\text { signifikansi }\end{array}$ & Kesimpulan \\
\hline Pretest & 0.115 & $\begin{array}{c}\text { Terdistribusi } \\
\text { normal }\end{array}$ \\
\hline Posttest & 0.581 & $\begin{array}{c}\text { Terdistribusi } \\
\text { normal }\end{array}$ \\
\hline
\end{tabular}

2. Uji Homogenitas

Tabel 6. Data Uji Homogenitas Varians pada uji kognitif dengan Levence Test

\begin{tabular}{ccc}
\hline Jenis Data & $\begin{array}{c}\text { Taraf } \\
\text { signifikansi }\end{array}$ & Kesimpulan \\
\hline Pretest & 0.642 & Varians homogen \\
Posttest & 0,134 & Varians homogen \\
\hline
\end{tabular}

C. Data Hasil Pengujian Hipotesis

1. Perbedaan hasil belajar ranah kognitif antara siswa dengan pendekatan "IDEAL" terbimbing menggunakan metode eksperimen dan metode demonstrasi.

Tabel 7. Data Uji Perbedaan Hasil Belajar Kognitif Siswa

\begin{tabular}{|c|c|c|c|c|c|}
\hline Hasil & \multicolumn{2}{|c|}{ Uji-F } & \multicolumn{3}{|c|}{ Uji-t } \\
\hline $\begin{array}{l}\text { Kognitif } \\
\text { Siswa }\end{array}$ & $\mathrm{F}$ & Sig & $\mathrm{T}$ & $\mathrm{df}$ & Sig \\
\hline $\begin{array}{c}\text { Equal } \\
\text { variances }\end{array}$ & & & 1,41 & 54 & 0,16 \\
\hline $\begin{array}{c}\text { assumed } \\
\text { Equal } \\
\text { variances } \\
\text { not assumed }\end{array}$ & 2,31 & 0,13 & 1,41 & 52,07 & 0,16 \\
\hline
\end{tabular}

2. Perbedaan hasil belajar ranah psikomotorik antara siswa dengan pendekatan "IDEAL" terbimbing menggunakan metode eksperimen dan metode demonstrasi.

Tabel 8. Data Uji Perbedaan Hasil Belajar Psikomotor Siswa

\begin{tabular}{cccccc}
\hline \multirow{2}{*}{ LKS $\begin{array}{c}\text { Hasil } \\
\text { belajar } \\
\text { psikomotor }\end{array}$} & $\mathrm{F}$ & $\mathrm{Uji}-\mathrm{F}$ & $\mathrm{t}$ & $\mathrm{df}$ & $\mathrm{Sig}$ \\
\cline { 5 - 7 } Equal \\
Eariance \\
1.
\end{tabular}

D. Pembahasan

Penelitian ini bertujuan untuk mengetahui perbedaan peningkatan dan hasil belajar ranah kognitif dan psikomotor antara siswa yang pendekatan dengan "IDEAL" terbimbing menggunakan metode eksperimen dan metode 
demonstrasi. Perbedaan kegiatan pembelajaran antara dua kelas disajikan pada Tabel 9.

Tabel 9. Proses Pembelajaran kelas eksperimen dan kontrol

\begin{tabular}{|c|c|c|}
\hline $\begin{array}{l}\text { Lang } \\
\text { kah }\end{array}$ & Kelas eksperimen & Kelas kontrol \\
\hline \multirow{10}{*}{$\begin{array}{l}\text { Ident } \\
\text { ify } \\
\text { Probl } \\
\text { em }\end{array}$} & $\begin{array}{l}\text { Identifikasi } \\
\text { masalah }\end{array}$ & $\begin{array}{l}\text { Identifikasi } \\
\text { masalah }\end{array}$ \\
\hline & dilakukan di meja & dilakukan \\
\hline & $\begin{array}{l}\text { kerja kelompok } \\
\text { masing-masing }\end{array}$ & $\begin{array}{l}\text { depan kelas yaitu } \\
\text { dengan }\end{array}$ \\
\hline & yaitu dengan & mengidentifikasi \\
\hline & mengidentifikasi & besaran-besaran \\
\hline & besaran-besaran & apa yang dapat \\
\hline & apa yang dapat & diukur \\
\hline & diukur dari & sebagain bahan \\
\hline & seluruh bahan & yang disediakan \\
\hline & yang disediakan. & $\begin{array}{l}\text { bagi masing- } \\
\text { masing kelompok } \\
\text { saja. }\end{array}$ \\
\hline \multirow{19}{*}{$\begin{array}{l}\text { Defin } \\
e \\
\text { Term }\end{array}$} & Siswa & Siswa \\
\hline & mendefinisikan & mendefinisikan \\
\hline & $\begin{array}{l}\text { masalah dengan } \\
\text { mengelompokkan } \\
\text { seluruh }\end{array}$ & $\begin{array}{l}\text { masalah dengan } \\
\text { mengelompokkan }\end{array}$ \\
\hline & $\begin{array}{ll}\text { seluruh } & \text { bahan- } \\
\text { bahan } & \text { sesuai }\end{array}$ & yang menjadi \\
\hline & dengan jenisnya & bagian masing- \\
\hline & (besaran pokok & masing kelompok \\
\hline & $\begin{array}{l}\text { atau turunan) dan } \\
\text { memperkirakan }\end{array}$ & $\begin{array}{l}\text { sesuai dengan } \\
\text { jenisnya (besaran }\end{array}$ \\
\hline & alat apa saja yang & pokok atau \\
\hline & dapat digunakan & turunan) dan \\
\hline & untuk mengukur & memperkirakan \\
\hline & besaran tersebut. & alat apa saja yang \\
\hline & kegiatan ini & dapat digunakan \\
\hline & dilakukan dimeja & untuk mengukur \\
\hline & $\begin{array}{l}\text { kerja masing- } \\
\text { masing kelomnok }\end{array}$ & besaran tersebut \\
\hline & & $\begin{array}{ll}\text { ukur yang } \\
\text { disediakan }\end{array}$ \\
\hline & & khusus untuk \\
\hline & & masing-masing \\
\hline & & kelompok dan \\
\hline & & $\begin{array}{l}\text { dilakukan } \\
\text { depan kelas }\end{array}$ \\
\hline
\end{tabular}

\begin{tabular}{llll}
\hline $\begin{array}{c}\text { Lang } \\
\text { kah }\end{array}$ & \multicolumn{2}{c}{ Kelas eksperimen } & \multicolumn{2}{c}{ Kelas kontrol } \\
\hline $\begin{array}{l}\text { Expl } \\
\text { ore }\end{array}$ & Eksplorasi cara & Eksplorasi cara \\
strat & dilakukan & & dilakukan \\
egys & kelompok siswa & kelompok siswa \\
& dengan mencoba & di depan kelas \\
& seluruh alat ukur & dengan mencoba \\
& yang ada untuk & alat ukur sebatas \\
& mengukur & yang telah \\
& besaran dari & diberikan pada \\
& bahan-bahan & masing-masing \\
& yang telah & kelompok untuk \\
& disediakan, & mengukur \\
& karena mencoba & besaran dari \\
& dengan seluruh & sebagian bahan- \\
& alatukuryang ada & bahan yang telah \\
& maka siswa & disediakan. \\
& diharapkan dapat & Dilakukan di \\
& memilih alat ukur & depan kelas
\end{tabular}

yang paling sesuai digunakan dalam mengukur suatu besaran tertentu. Dilakukan dimeja kerja masingmasing kelompok

Act Menerapkan cara on yang paling the sesuai, yakni Strat dengan egy menggunakan alat ukur yang paling sesuai untuk mengukur suatu besaran tertentu.

Dilakukan di meja kerja masingmasing kelompok

Menerapkan cara yang paling sesuai, yakni dengan menggunakan alat ukur yang paling sesuai untuk mengukur suatu besaran tertentu dan karena kurang leluasa dalam melakukan eksplorasi cara pengukuran maka kemungkinan untuk salah dalam memilih alat ukur yang paling sesuai untuk melakukan pengukuran suatu 


\begin{tabular}{|c|c|c|}
\hline $\begin{array}{l}\text { Lang } \\
\text { kah }\end{array}$ & Kelas eksperimen & Kelas kontrol \\
\hline $\begin{array}{l}\text { Look } \\
\text { at } \\
\text { the } \\
\text { Effec } \\
t\end{array}$ & $\begin{array}{l}\text { Membandingkan } \\
\text { hasil pengukuran } \\
\text { suatu besaran } \\
\text { dengan seluruh } \\
\text { alat ukur yang } \\
\text { telah dilakukan, } \\
\text { dari hasil } \\
\text { perbandingan } \\
\text { hasil pengukuran } \\
\text { ini siswa dapar } \\
\text { mengurutkan alat } \\
\text { ukur mana yang } \\
\text { mempunyai } \\
\text { tingkat ketelitian } \\
\text { paling parg } \\
\text { pengukuran } \\
\text { paling tinggi dari } \\
\text { suatu besaran. } \\
\text { Dilakukan di meja } \\
\text { kelompok } \\
\text { masing-masing. }\end{array}$ & $\begin{array}{l}\text { besaran lebih } \\
\text { besar } \\
\text { dibandingkan } \\
\text { siswa kelas } \\
\text { eksperimen. } \\
\text { Dilakukan di } \\
\text { depan kelas } \\
\text { Membandingkan } \\
\text { hasil pengukuran } \\
\text { suatu besaran } \\
\text { dengan alat ukur } \\
\text { dijatahkan pada } \\
\text { masing-masing } \\
\text { kelompok, karena } \\
\text { dalam } \\
\text { membandingkan } \\
\text { hasil pengukuran } \\
\text { dengan alat ukur, } \\
\text { siswa pada } \\
\text { kelompok ini } \\
\text { tidak mempunyai } \\
\text { data lengkap dari } \\
\text { kelompoknya } \\
\text { sendiri tentang } \\
\text { hasil pengukuran } \\
\text { seluruh alat maka } \\
\text { siswa tidak bisa } \\
\text { mengurutkan alat } \\
\text { dari yang } \\
\text { mempunyai } \\
\text { ketelitian kecuali } \\
\text { tertinggi kan denging } \\
\text { dengan } \\
\text { bekerjasama } \\
\text { dengan kelompok } \\
\text { lain. Dilakukan } \\
\text { dimeja kelompok } \\
\text { masing-masing. }\end{array}$ \\
\hline
\end{tabular}

Keberhasilan kelompok demostrasi dalam mengisi LKS dan mengerjakan tugas dipengaruhi oleh hasil kerja kelompok lain dan perhatian mereka terhadap demonstrasi kelompok lain yang melakukan demonstrasi di depan kelas sedangkan pada kelas eksperimen, keberhasilan kelompok dalam mengisi LKS dan mengerjakan tugas tergantung pada masing-masing kelompok selama melakukan percobaan atau pengukuran tanpa ada pengaruh dari kelompok lain. Dengan adanya perbedaan langkah-langkah dalam pembelajaran dalam dua kelas sample, yaitu kelas eksperimen diberikan pembelajaran menggunakan pendekatan "IDEAL" terbimbing menggunakan metode eksperimen dan kelas kontrol diberikan pembelajaran dengan pendekatan "IDEAL" terbimbing menggunakan metode demonstrasi maka menyebabkan perbedaan hasil belajar yang diperoleh siswa pada masing-masing kelas sampel.

1. Perbedaan hasil belajar ranah kognitif antara siswa dengan pendekatan "IDEAL" terbimbing menggunakan metode eksperimen dan metode demonstrasi.

Dari 28 siswa untuk masing-masing kelas sampel didapatkan rata-rata skor kemampuan awal fisika siswa kelas eksperimen sebesar 14,39 dan kelas kontrol sebesar 13,96. Kedua rerata kelas eksperimen tersebut tidak jauh berbeda dan terletak pada rentang yang sama maka dapat dinyatakan bahwa siswa pada kedua kelas tersebut memiliki kemampuan yang sama. Untuk lebih memastikan kesamaan rerata kemampuan awal dari siswa dilakukan uji homogenitas. Berdasarkan tabel 6 diketahui bahwa data kemampuan awal memiliki $\mathrm{P}>0,05$ sehingga kedua kelompok memiliki varians yang sama atau disebut dengan homogen.

Setelah mengalami proses pembelajaran dan perlakuan yang berbeda, siswa diberi tes hasil belajar kognitif siswa. Berdasarkan tes yang telah dilakukan didapatkan skor rata-rata hasil belajar kognitif siswa kelas eksperimen sebesar 20,61 dan untuk kelas kontrol sebesar 18,39. Rerata nilai posttest kedua kelas eksperimen menunjukkan adanya perbedaan. Namun untuk mengetahui apakah perbedaan tersebut signifikan atau tidak maka dilakukan uji-t (independent sample t-test) pada nilai post-test. Hasil perhitungan independent sample t test untuk 
kedua kelompok pada nilai post-test dapat dilihat pada tabel 7.

Berdasarkan uji-t pada taraf signifikansi $5 \%$ diperoleh nilai thitung < ttabel yaitu sebesar 1,475 dan nilai phitung $>0,05$ artinya tidak terdapat perbedaan rerata yang signifikan antara kedua kelas.

Berdasarkan hasil penelitian di atas dapat dikatakan bahwa penggunaan pendekatan "IDEAL" terbimbing dengan metode eksperimen belum menunjukkan perbedaan hasil belajar fisika ranah kognitif bila nilai siswa dibandingkan dengan nilai kelas dengan pembelajaran dengan menggunakan pendekatan "IDEAL" terbimbing dengan metode demonstrasi. Hal ini disebabkan karena dalam kelas kontrol guru bisa langsung membenarkan kesalahan yang dilakukan siswa bila melakukan kesalahan pada saat melakukan demonstrasi dan kelompok lain pun bisa melihatnya bahkan mengetahui percobaan yang salah dan yang benar sekaligus, akan lebih mengena pada masing-masing siswa sedangkan pada kelas eksperimen kesalahan siswa saat melakukan percobaan tidak bisa langsung dibenarkan oleh guru karena jumlah siswa atau kelompok yang cukup banyak sehingga sulit mengamati jalannya proses percobaan secara bersamaan. Selain itu, keunggulan dari pembelajaran menggunakan metode demonstrasi memerlukan waktu yang relatif lebih singkat dibandingkan pembelajaran yang menggunakan metode eksperimen sehingga pada kelas kontrol siswa mempunyai waktu lebih lama dalam membahas hasil kegiatan dan latihan soal bersama guru. Padahal pada ujian pretes dan postes banyak soal yang berupa hitungan atau konversi satuan sehingga membutuhkan latihanlatihan. Hal ini akan membuat siswa pada kelas kontrol lebih siap dan terbiasa menghadapi soalsoal yang diberikan dibandingkan siswa pada kelas eksperimen.

2. Perbedaan hasil belajar ranah psikomotorik antara siswa dengan pendekatan "IDEAL" terbimbing menggunakan metode eksperimen dan metode demonstrasi.

Penilaian terhadap hasil belajar psikomotor siswa dilakukan selama perlakuan diberikan kepada kedua kelompok. Penilaian dilakukan menggunakan lembar observasi psikomotor. Instrumen psikomotor tersebut disesuaikan dengan lembar kegiatan yang dilakukan oleh siswa. Dalam penelitian ini ada 5 LKS yang masing-masing memilki 6 jenis kegiatan yang berbeda.

Berdasarkan penilaian hasil belajar psikomotor yang diperoleh dari pengamatan observer didapatkan rerata untuk kelas eksperimen secara berturut-turut dari instrumen psikomotor pada kegiatan 1, kegiatan 2, kegiatan 3, kegiatan 4, dan kegiatan 5 adalah 14,98; 16,46; 16,38; 14,91 dan 14,98. Sedangkan rerata untuk kelas kontrol secara berturut-turut dari instrumen psikomotor pada kegiatan 1, kegiatan 2, kegiatan 3, kegiatan 4 dan kegiatan 5 adalah 13,48; 13,6; 14,09; 14,04 dan 13,55 .

Hasil rerata nilai psikomotor untuk masingmasing kegiatan pada kelas eksperimen dan kelas kontrol menunjuk hasil yang berbeda. Hal ini menunjukkan bahwa kedua kelas memiliki kemampuan psikomotor yang relatif berbeda. Untuk lebih memastikan ada atau tidaknya perbedaan maka dilakukan uji-t pada hasil belajar psikomotor. Uji hipotesis pada hasil belajar psikomorik menunjukkan bahwa ada perbedaan yang signifikan antara siswa yang menggunakan pendekatan "IDEAL" terbimbing dengan metode eksperimen dan metode demonstrasi pada pokok bahasan pengukuran di SMP N 1 Tanjungsari. Penjelasan yang lebih lengkap dapat dilihat pada penjelasan tabel 8.

Pada hipotesis diperkirakan bahwa hasil belajar psikomotor siswa dengan pendekatan "IDEAL" terbimbing dengan metode eksperimen lebih tinggi dari pada hasil belajar psikomotorik siswa dengan pendekatan "IDEAL" terbimbing dengan metode demonstrasi. Ada beberapa faktor yang mempengaruhi hasil belajar siswa kelas dengan metode eksperimen lebih tinggi 
dibandingkan siswa kelas dengan metode demonstrasi.

Berikut faktor yang mempengaruhi perbedaan hasil belajar ranah psikomotorik dari kedua kelas.

Tabel 10. Tabel Perbedaan Kegiatan Siswa

\begin{tabular}{|c|c|c|}
\hline Faktor & $\begin{array}{l}\text { Kelas dengan } \\
\text { metode } \\
\text { eksperimen }\end{array}$ & $\begin{array}{l}\text { Kelas dengan } \\
\text { metode } \\
\text { demonstrasi }\end{array}$ \\
\hline $\begin{array}{c}\text { Freku } \\
\text { ensi } \\
\text { perco } \\
\text { baan }\end{array}$ & $\begin{array}{l}\text { Memperoleh } \\
\text { frekuensi } \\
\text { melakukan } \\
\text { percobaan lebih } \\
\text { banyak karena } \\
\text { tiap kelompok } \\
\text { melakukan } \\
\text { pengukuran pada } \\
\text { semua besaran } \\
\text { yang ada sehingga } \\
\text { keterampilan } \\
\text { siswa dalam } \\
\text { menggunakan } \\
\text { alat ukur lebih } \\
\text { terasah }\end{array}$ & $\begin{array}{l}\text { Memperoleh } \\
\text { frekuensi } \\
\text { melakukan } \\
\text { percobaan lebih } \\
\text { sedikit karena } \\
\text { tiap kelompok } \\
\text { hanya } \\
\text { melakukan } \\
\text { pengukuran } \\
\text { pada sebagian } \\
\text { besaran saja } \\
\text { sehingga katerampilan } \\
\text { siswa dalam } \\
\text { melakukan } \\
\text { pengukuran } \\
\text { lebih rendah }\end{array}$ \\
\hline Temp & Masing-masing & Masing-masing \\
\hline & kelompok bekerja & kelompok \\
\hline $\begin{array}{l}\text { kerja } \\
\text { dalam } \\
\text { melak }\end{array}$ & $\begin{array}{l}\text { di meja kerja } \\
\text { kelompok } \\
\text { masing-masing }\end{array}$ & $\begin{array}{l}\text { melakukkan } \\
\text { percobaan di } \\
\text { depan kelas }\end{array}$ \\
\hline $\begin{array}{l}\text { ukan } \\
\text { perco } \\
\text { baan }\end{array}$ & $\begin{array}{lr}\text { sehingga } & \text { lebih } \\
\text { santai } & \text { dan } \\
\text { nyaman } & \end{array}$ & $\begin{array}{l}\text { sehingga muncul } \\
\text { rasa malu dan } \\
\text { grogi pada saat } \\
\text { melakukan } \\
\text { percobaan }\end{array}$ \\
\hline $\begin{array}{l}\text { Keterli } \\
\text { batan } \\
\text { anggot } \\
\text { a }\end{array}$ & $\begin{array}{l}\text { Masing-masing } \\
\text { anggota ikut serta } \\
\text { berperan dalam } \\
\text { melakukan } \\
\text { percobaan } \\
\text { meskipun } \\
\text { kualitas kerja } \\
\text { masing-masing } \\
\text { anggota tidak } \\
\text { sama }\end{array}$ & $\begin{array}{l}\text { Tiap-tiap } \\
\text { anggota } \\
\text { kelompok } \\
\text { cenderung } \\
\text { mengandalkan } \\
\text { sebagian } \\
\text { anggota } \\
\text { kelompok } \\
\text { tertentu dalam } \\
\text { melakukan }\end{array}$ \\
\hline
\end{tabular}

\begin{tabular}{|c|c|c|}
\hline Faktor & $\begin{array}{l}\text { Kelas dengan } \\
\text { metode } \\
\text { eksperimen }\end{array}$ & $\begin{array}{l}\text { Kelas dengan } \\
\text { metode } \\
\text { demonstrasi }\end{array}$ \\
\hline $\begin{array}{l}\text { Pengis } \\
\text { ian } \\
\text { LKS }\end{array}$ & $\begin{array}{l}\text { masing-masing } \\
\text { kelompok dapat } \\
\text { mengisi LKS } \\
\text { sesuai dengan apa } \\
\text { yang diperoleh } \\
\text { dari percobaan } \\
\text { mereka }\end{array}$ & $\begin{array}{l}\text { demonstrasi } \\
\text { percobaan } \\
\text { sebagaian besar } \\
\text { berdasarkan } \\
\text { hasil } \\
\text { pengukuran } \\
\text { kelompok lain } \\
\text { yang melakukan } \\
\text { demonstrasi }\end{array}$ \\
\hline
\end{tabular}

Selain itu juga kemungkinan muncul rasa bosan pada kelas kontrol lebih besar dari pada kelas eksperimen, karena harus memperhatikan demonstrasi-demonstrasi kelompok lain, beda halnya dengan kelompok kelas eksperimen yang justru akan memunculkan rasa tertarik dan memancing keaktifan masing-masing anggota kelompok.

Pada kenyataannya asumsi-asumsi diatas memang berpengaruh terhadap hasil belajar siswa pada ranah kognitif, hai ini nampak pada uji perbedaan hasil belajar psikomotor dengan perhitungan independent sample $t$ test yang menunjukkan hasil belajar siswa ranah psikomotorik pada kelas eksperimen lebih tinggi dari pada kelas kontrol kecuali pada percobaan keempat yaitu pada percobaan pengukuran besaran waktu, hal ini dikarenakan pada percobaan pengkuran besaran waktu di kelas eksperimen kurang persiapan dari peneliti yaitu kurangnya alat yang ada baik arloji, jam tangan (jam analog) maupun jam digital (Hp) sehingga dalam kegiatannya masing-masing kelompok kelas eksperimen harus bergantian dalam menggunakan alat dan ketidakteraturan dalam bergiliran menggunakan alat menyebabkan ketidakteraturan pula dalam melakukan percobaan. sedangkan pada kelas kontrol penggunaan alat-alat ukur besaran waktu tersebut bisa bergantian sehingga kegiatan pengukuran dalam kelas dengan metode demonstrasi dapat berjalan dengan baik. 


\section{KESIMPULAN}

Berdasarkan hasil penelitian dan analisis data dapat disimpulkan bahwa:

1. Tidak ada perbedaan hasil belajar siswa pada ranah kogitif dalam pembelajaran fisika dengan pendekatan "IDEAL" terbimbing menggunakan metode eksperimen dan metode demonstrasi pada pokok bahasan pengukuran di SMP N 1 Tanjungsari.

2. Ada perbedaan yang positif dan signifikan hasil belajar siswa pada ranah psikomotor antara siswa dengan pendekatan "IDEAL" terbimbing menggunakan metode eksperimen dan metode demonstrasi pada pokok bahasan pengukuran di SMP N 1 Tanjungsari.

\section{DAFTAR PUSTAKA}

Ahmad Abu hamid dkk. (1991). Al Qalam. Yogyakrta: duta Pustaka

Akhmad Sudrajad. (www.psb.psma.org). 4/22/2009

Budi Prasodjo dkk. (2006). Teori dan Aplikasi Fisika SMP Kelas VII 1. Bogor: Yudhistira

Hamzah B. Uno, dkk. (2001). Pengembangan Instrumen untuk Penelitian. Jakarta: Delima Press.

Marthen Kanginan. (2002). Sains Fiska SMP. Jakarta: Erlangga

Margono. (2009). Metode Penelitian Pendidikan. akarta: Asdi Mahasatya

Nana Syaodih Sukmadinata. (2006). Metode Penelitian Pendidikan. Bandung: Remaja Rosdakarya.

Sri rumini dkk. 1993. Psikologi Pendidikan. Yogyakarta: UPP Universitas Negeri Yogyakarta

Sugiyono. (2008). Statistika Untuk Penelitian. Bandung: Alfabeta

\section{. (2009).Metode Penelitian Pendidikan.} Bandung: Alfabeta

Suharsimi Arikunto. (1993). Dasar-dasar Evaluasi Pendidikan. Jakarta: Bumi Aksara.

Sukamto dkk. 1991. Pedoman Penelitian. Yogyakarta: Pusat Penelitian IKIP Yogyakarta

Supriyadi. (2007). Kurikulum Sains dalam Proses Pembelajaran Sains. Yogyakarta: Pustaka Tempel Sari.
Paul Suparno. (2007). Metodologi Pembelajaran Fisika Konstruktivistik dan Menyenangkan. Yogyakarta: Universitas Sanata Dharma.

Saifuddin Azwar.(1996).Tes Prestasi Fungsi dan Pengembangan Pengukuran Prestasi Belajar.Yogyakarta:Pustaka Pelajar.

Syaiful Sagala.2008. Konsep dan Makna Pembelajaran. Bandung : Alfabeta

Throwbridge, Leslie W., dan Bybee, Rodger W. (1990). Becoming a Secondary School Science Teacher. Ohio: Merril Publishing Company.

Triton PB. (2006). SPSS 13.0 Terapan Riset Statistik Parametrik. Yogyakarta: ANDI. 